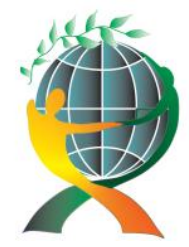

\author{
(online) $=$ ISSN $2285-3642$ \\ ISSN-L = $2285-3642$ \\ Journal of Economic Development, Environment and People \\ Volume 1, Issue 3, 2012 \\ URL: http://jedep.spiruharet.ro \\ e-mail: office jedep@spiruharet.ro
}

\title{
Social Responsible Marketing - Yesterday and Today
}

\author{
Milena Ilic, Magistra \\ Public Utility Service "Gradsko stambeno", Belgrade \\ Danijelova 33, Belgrade \\ Tel. +38164/8950.416 \\ E-mail: milena.ilic@stambeno.com \\ Branislav Radnovic, phd \\ Faculty of Business Economy \\ Educons University. Sremska Kamenica - Novi Sad \\ Vojvode Putnika bb \\ Tel: +38121/4893-630 \\ E-mail: rabanyu@yahoo.com \\ Zoran D. Zivkovic, Msc \\ Public Utility Service „Gradsko stambeno“, Belgrade \\ Danijelova 33, Belgrade \\ Tel. +38164/8950.277 \\ E-mail: zoran.zivkovic@stambeno.com
}

\begin{abstract}
Several factors direct the companies to apply a higher level of corporate social responsibility: the increasing expectations of customers, changes in expectations of employees, laws and government pressure, investor interest in the social criteria and changes in supply practices

The basic principles of socially responsible marketing as an ethical business, respect for ecological principles and respect for the legislation. Organizations must ensure that all employees know and observe the relevant laws.
\end{abstract}




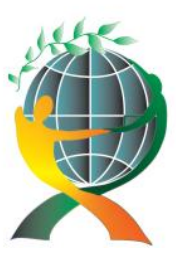

\author{
(online) $=$ ISSN $2285-3642$ \\ ISSN-L = $2285-3642$ \\ Journal of Economic Development, Environment and People \\ Volume 1, Issue 3, 2012 \\ URL: http://jedep.spiruharet.ro \\ e-mail: office jedep@spiruharet.ro
}

Companies must adopt and make available to the written rules of ethics, to develop tradition of ethical conduct in the company and impose a responsibility to his men to follow ethical and legal guidelines.

By adopting these or similar principles, companies can create opportunities to reduce current and future costs, strengthen competitiveness and market position and achieving greater profits.

In contemporary business, more ecological component is present in the execution of business activities as an important prerequisite for improving competitive advantage and company image. Awareness of the issue of environmental protection in companies has evolved primarily as a result of the influence of customers and various non-governmental and non-profit organizations on marketing orientation of companies, and the requirements for the development of products and services that meet environmental standards and consumer needs.

Keywords: socialy responsible marketing, ethical business, ecologicac principles

JEL Codes: M31, M14, Q57

\title{
1. Introduction
}

To exercise a success in business, with continuous customer satisfaction and all stakeholders, can be associated with acceptance and implementation of high standards of relationship marketing. In order to achieve business goals and success in the marketplace, that have been set, companies must imperatively practice ethically and socially responsible marketing. Ethics has become a key element of the interaction between the company and its stakeholders.

Corporate social responsibility means that the corporation build's up and fosters its position on ethical values and acceptable to the entire community in which the corporation exists, including its financial and organizational capacity to practically implement its desired action.

This paper deals with the concept of corporate social responsibility, historical and contemporary, concepts of relationship marketing and socially responsible marketing.

\section{Concept of a Socially Responsible Business}

\subsection{The emergence of the concept of corporate social responsibility}

In the last century, the late eighties, a concept of corporate social responsibility - CSR (Corporate Social Responsibility) has been created. This business concept means that companies voluntarily participate in their own business and in relationships with partners, concerns about social and environmental aspects of its operations. (Declaration of the European Union). 


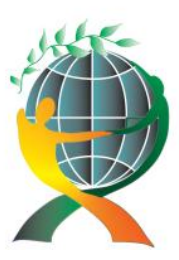

\author{
(online) $=$ ISSN $2285-3642$ \\ ISSN-L = $2285-3642$ \\ Journal of Economic Development, Environment and People \\ Volume 1, Issue 3, 2012 \\ URL: http://jedep.spiruharet.ro \\ e-mail: office jedep@spiruharet.ro
}

Socially responsible business enterprise reflects its level of development and quality of life in the local, but also in a wider community, through active participation of the enterprise in solving problems of its employees, economy, energy and environmental problems at the community level. Environmental protection is one of the primary concerns of an enterprise in its business on the market. By making efforts to preserve the natural environment businesses can reduce the negative impact on the environment on a possible minimal extent

One might ask, what is the purpose of business organizations? Is it focused solely on maximizing profits to its shareholders, or the company may have a greater responsibility to assist in solving of social problems?

In the seventies there was a lot of discussing about the three types of social responsibility. First, there was a discussion about how business people should behave on the job. Do you need to have moral standards - principles - that they have in their private lives? One issue that has often been debated is, whether the director should bribe a person in order to ensure a contract, in case he knows that his competitors are likely to do the same. Second, there was a discussion about the social responsibility of firms according to their own workers. Interest was focused on how organizations can make improvements of working conditions for their employees. Finally, social responsibility included the idea that business people should contribute to cultural activities or to support activities such as music festivals and art exhibitions. Since managers are also expected to serve in a educational committee, Hospital administrative cost projects, etc.. In other words, they had to actively participate in the life of their communities.

Corporate Social Responsibility by Philip Kotler and Nancy Lee, represents a commitment to improve communities well-being through discretionary business practices and contribute to the account of corporate resources. A key element of this definition is the word discretion. It is not about business activities that are required by the law or by their moral or ethical nature that is expected as such. It is a voluntary, unsolicited activity of a firm and its decision to select and apply the practice of a business and to make contributions. This commitment must be demonstrated so that the companies could be called socially responsible, and that is implemented through adoption of new business practices and contributions, both cash and in-kind. Term benefit of the community in this definition implies conditions of the people in the community itself, and of course, environmental issues.

\title{
2.2. New ways in addressing social responsibility
}

Nowadays there is a new approach in the consideration of social responsibility. Many believe that companies, in addition to their own, should meet the needs and interests of society. They have a responsibility to assist in solving problems in society itself. This new concept has influenced the growth of society's expectations in relation to business organizations. For example, continuing to put pressure on 


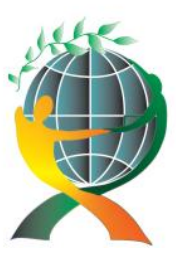

\author{
(online) $=$ ISSN $2285-3642$ \\ ISSN-L = $2285-3642$ \\ Journal of Economic Development, Environment and People \\ Volume 1, Issue 3, 2012 \\ URL: http://jedep.spiruharet.ro \\ e-mail: office jedep@spiruharet.ro
}

organizations to provide safer and more secure environment for people. Because of some companies, such as chemical industries, it is expected to not only meet the states standards in terms of pollution, but it also must take steps in reducing pollution as much as possible even at the cost of reduced profits.

In a modern society, the companies are expected to show they are socially responsible in many ways. They are encouraged to produce safer products, to protect and respect the environment, to recruit people from minorities, create jobs for unemployed young people, to oppose racial discrimination and to maintain a high degree of integrity in the process.

Banking has the best example of this new approach. The once famous British bank is under pressure to cease its operations in South Africa because many of their clients were opposing South Africa's Apartheid politics.

A new concept of social responsibility means that companies and business people alike must have integrity. They have to be honest with their workers and the outer world. Successful companies are very vulnerable in the event when their integrity is put into question. Their reactions are often severe and they include extensive media coverage.

Many business people agree with this broader concept of social responsibility. They also agree that companies should help in solving social problems, even when their company is not the cause of these problems.

But there are those who are against this approach. Thus, an American economist and Nobel laureate Milton Friedman believes that firms have only one responsibility and that is to "pool their resources and energy in activities that aim to increase profits as long as they keep within the rules of the game ... and to engage in open and free competition without any form of deception and fraud. "Friedman claims that the social responsibility of companies is to" make as much money for their shareholders as possible. "Another famous person from the world of business has a similar attitude. Jan McGregor (lan MacGregor), former CEO and chairman of the managing boards of large British companies said that the first priority for companies is to create wealth. Many companies, in his opinion, have the concept of social responsibility which deters them from what their main task is.

It is a fact that social actions cost a lot of money, and because of that a company that finances them often raises prices of their products because of that, or they reduce wages of its workers or earns less profit. Someone eventually has to pay the costs of social actions - this could be a customer, an employee or a shareholder.

Of course, companies can also benefit from demonstration of social responsibility in the long run. Important social and cost-effective projects which the leading companies are involved in provide equipment for the university, seminars and project-related informational technology, and training programs at universities and colleges, and seminars on career development, sponsorship of art and sports competitions. Sometimes social activities are a part of the company's business strategy. This is not about will the charity be 


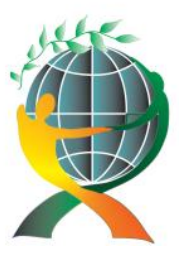

\author{
(online) $=$ ISSN $2285-3642$ \\ ISSN-L = $2285-3642$ \\ Journal of Economic Development, Environment and People \\ Volume 1, Issue 3, 2012 \\ URL: http://jedep.spiruharet.ro \\ e-mail: office jedep@spiruharet.ro
}

worth mentioning only briefly in the company's annual report. Large companies often have contracts with state structures and other social groups. Employment of expert and highly educated work force so is in the best interest of the company, and because of that its social programs is equally important to its overall success. There is no doubt that, in the long run, these activities will be extremely profitable for the organization itself.

In the literature one can find the statement that started the practice of social responsibility as a means of managing the risk in large multinational companies, who were exposed to attacks because of its policies toward the environment or personnel. For these reasons they have adopted a proactive behaviour or practice that is in advance committed towards sensitivity of the environment and communities in which they operate. The essence of corporate social responsibility is that it is in relation to the environment and society that goes beyond what is required by law. It is also important to establish a real dialogue and cooperation between enterprises and organizations in the non-profit sector.

Any job, either big or small, is not separated from the society in which it operates. Success or failure of the one is largely determined by the success or failure of the other. People are really interested in the way the company treats them, and also in the environment and society in general. However, it is not enough to formally announce their commitment, in addition to the formal announcement, presentation of the commitment is necessary in order to show that it is real and that it brings real results, including identification of those procedures and actions that can bring benefits to the principal activity of enterprises and society as a whole.

The reasons for the introduction of CSR are ethical (moral standards), sustainability (it makes sense when the application has economically justified measures - reducing energy consumption and less waste, but it is harder to justify it in other cases - corruption, transparency), working license (represents a means to cope with issues important to the shareholders, to encourage dialogue with the public, legislators, etc.).

Directly related to the concept of corporate social responsibility is the civil society and non-profit sector. Providing of sufficient funds, grants, donations, scholarships for activists and users, is one of the crucial aspects of the performance and survival of any non-profit organization. Sources of funds for the general benefit of society through non-governmental organizations are provided thanks to socially responsible companies. Although in some cases we may rightly ask is it altruism and social responsibility or it is a cleverly devised marketing strategy. ${ }^{1}$

\footnotetext{
${ }^{1}$ Radnović B., Ilić M, Živković Z, Corporate Social Responsibility and the nonprofit sector - a unethical marketing strategy or genuine concern, 3rd International Conference of Economic Sciences, Kaposvar 2011.
} 


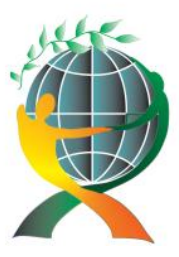

\author{
(online) $=$ ISSN $2285-3642$ \\ ISSN-L = $2285-3642$ \\ Journal of Economic Development, Environment and People \\ Volume 1, Issue 3, 2012 \\ URL: http://jedep.spiruharet.ro \\ e-mail: office jedep@spiruharet.ro
}

\title{
2.3. Standard ISO 26000:2010 and SRPS ISO 26000
}

At the end of 2010 a long-awaited international standard ISO 26000:2010 social responsibility Instructions on social responsibility has been adopted. Serbian response is the national standard SRPS ISO 26000:2011. This standard is a comprehensive and practical way to assist all organizations, regardless of their size and activity, to discover in which area and in what way they can achieve improvement in social responsibility. The standard is designed in a way to serve - organizations that are relatively new in dealing with social responsibility, as well as organizations that have achieved a high level of maturity on this issue.

Standard ISO 26000:2010 contains the following chapters:

- Subject and area of application,

- Terms and definitions,

- Understanding of the social responsibility,

- Principles of social responsibility,

- Recognition of social responsibility and stakeholder engagement,

- Instructions on the key issues of social responsibility,

- Instructions on integrating social responsibility into the organization.

Chapter 3 is of particular importance for small organizations because it includes instructions for using the standards in small and medium-sized organizations. Throughout this chapter is described a concept of social responsibility - what it means and how it applies to the organization.

Chapter 4 explains the basic principles of social responsibility: accountability, transparency, ethical behaviour, respecting of the stakeholders interests, respecting the rule of law, respecting for international norms of conduct, respecting of human rights.

Chapter 5 provides instructions of the relationship between the organization, its stakeholders and society, recognizing the fundamental issues and questions of social responsibility and the sphere of influence of the organizations.

Chapter 6 explains the key topics relating to social responsibility: management of the organization, human rights, labour practices, environment, fair business, issues and consumer involvement in the community and its development.

Chapter 7 provides guidance on the practical application of social responsibility in the organization 


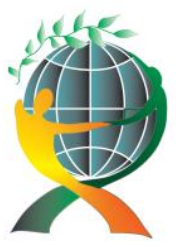

\author{
(online) $=$ ISSN $2285-3642$ \\ ISSN-L = $2285-3642$ \\ Journal of Economic Development, Environment and People \\ Volume 1, Issue 3, 2012 \\ URL: http://jedep.spiruharet.ro \\ e-mail: office jedep@spiruharet.ro
}

When it comes to social responsibility in Serbia, Standard SRPS ISO 26000, which represents guidance for the basic principles of socially responsible behavior of companies and organizations represented in the Serbian Chamber of Commerce. The recently published standard is the same as the international standard ISO 26000 in fact it is its translation into Serbian. SRPS ISO 26000, are guidelines for developing awareness of socially responsible behavior of companies and organizations. This standard may apply for the companies and organizations of any kind, and it provides a competitive advantages and sustainable development.

The goal of social responsibility contributes to sustainable development. ISO 26000 was published in late 2010. in Geneva, and SRPS ISO 26000 was published six months later.

\title{
3. Marketing Concept of Social Responsibility
}

\subsection{Marketing as a necessity}

Marketing orientation is not only desirable but is also necessary in the service industry businesses. There is little prospect of lasting business success if there is no monopoly on the market itself, or if the business activities in the domestic and international markets are not marketing-oriented. In developing strategies of service businesses it is necessary to have information about the state of the environment and a realistic assessment of the company. A successful marketing strategy is one that allows you to create consumer interest in services companies, so that it comes to sales, and also to secure new sales. ${ }^{2}$

The main goal of marketing is increasingly becoming a development of close and long-term relationships with individuals and organizations that can influence the success of marketing activities of companies. Relational marketing approach recognizes the importance of different stakeholders to deliver the best value for the consumer. The ultimate result of relational marketing is to build unique marketing networks, composed of the company and its stakeholders with which the company builds profitable relationships. ${ }^{3}$

Marketing brings a new style of work in the business, creates new obligations, shows discipline in executing the plan and it is committed to the development of comprehensive cooperation and coordination of all participants in the business process. ${ }^{4}$

\footnotetext{
${ }^{2}$ Todorović, J., M. Milisavljević, "Marketing strategy", Faculty of Economics, Belgrade, 1991.

${ }^{3}$ Filipović V, Kostić M, "Marketing - Theory and Practice", FON, Belgrade, 2005.

${ }^{4}$ Filipović V., Kostić - Stanković M., Marketing Management, FON, Belgrade, 2007.
} 


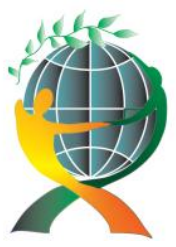

\author{
(online) = ISSN $2285-3642$ \\ ISSN-L = $2285-3642$ \\ Journal of Economic Development, Environment and People \\ Volume 1, Issue 3, 2012 \\ URL: http://jedep.spiruharet.ro \\ e-mail: office jedep@spiruharet.ro
}

The views of stakeholders are involved in marketing through the marketing orientation, relational marketing, brand management, public relations and marketing communications. In the concept of corporate marketing, stakeholders are viewed not only as buyers of products and services, but as factors under which the concept of marketing mix is extended and adjusted by. Corporate marketing orientation aims to create value beyond profit maximization and to take care of social needs and expectations, including the stakeholders. Thus, one of the most important elements of corporate marketing, from the perspective of social responsibility, is the social interaction.

Marketing is a modern scientific discipline, which is the result of natural processes and lawful business orientation caused by the evolution of economic entities in market economies.

Marketing is a term that has different meanings:

- Business concept;

- Business Function;

- Economic process;

- Business System;

- Scientific discipline.

Marketing as a business concept represents companies active attitude towards the market-market orientation in terms of marketing as a business philosophy, which means that the business orientation of economic entities towards the market. It is based on pre-viewed needs of the consumers and, on that basis, their satisfaction with the specific value of the use itself, with the achievement of planned business results. Pre-perceived needs of consumers represent the starting and the final link in the chain of formulating marketing concept in business enterprises.

Marketing as a business function involves researching, identifying and analyzing the needs and demands of consumers, in order to respond to them with adequate range of products and services, in the right place at the right time, for the appropriate prices (which consumers are willing to pay). That is the function of marketing management - planning includes all activities and organizational directional offers from producers 6 to consumers. Marketing as a business concept provides an active position in the enterprise market.

Marketing as a business concept includes a stance of the company toward its role in the economy and society and the "means of identification aimed at meeting the needs of citizens as consumers, and also the economy and society in certain products and services to get the realization it needs ${ }^{\prime 5}$. This concept is based

\footnotetext{
${ }^{5}$ Milisavljević M., Marketing, Modern Administration, Belgrade, 2003.
} 


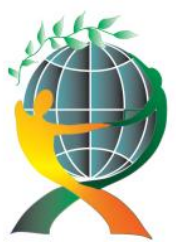

\author{
(online) $=$ ISSN $2285-3642$ \\ ISSN-L = $2285-3642$ \\ Journal of Economic Development, Environment and People \\ Volume 1, Issue 3, 2012 \\ URL: http://jedep.spiruharet.ro \\ e-mail: office jedep@spiruharet.ro
}

on the knowledge that in the economy where the market has a decisive role, the fate and livelihood of an enterprise depends on it. Therefore, all activities must have their origin in the needs, demands of customers, but also in their difficulties and problems. Bearing in mind the aforesaid, it is often that the marketing concept is called market orientation in the literature. Orientation does not mean just the existing business (won), but as well as penetration into new markets.

Marketing as a business concept suggests a specific way of planning, setting and realizing business opportunities of companies. "The specificity of thought and operational approach is reflected in, above all, in the means that marketing is active (offensive, and in practice today is often encountered and aggressive) approach to all forms of economic life, especially in the business activities of enterprises'. 6

The modern concept of marketing requires and demands application integration, synchronization and coordination of activities related to companies. All marketing activities should contribute to economic efficiency and meet consumer needs, economy and society. From what is stated above, we inferred that such management and marketing management organization, provides an adequate evaluation of the symbiosis of market, economic and broader social interests. Also, the very essence of marketing is its timely ability to adapt to the changes and demands of society and markets. Due to that positive fact, marketing is considered one of the instruments suitable for the implementation of necessary structural changes.

The goal of business-oriented marketing firms is representing the needs of consumers and its adequately meeting, because that is the key to achieving the primary goals of existence, business and enterprise development. Consumer needs should primarily be identified, and examined, then to determine target markets, and then to plan production and sales program and other marketing activities. In addition, ways must and methods must be found that will ensure the efficient use of available resources in order to gain competitiveness in the market. If the company in its mission does not find ways to attract and retain customers and consumers, it will not last long. It should always be borne in mind that meeting the needs of customers and consumers is the main task and purpose of all jobs in the company.

Marketing as an economic process, has in its focus a process of exchange, and brings us into contact production and consumption, connecting them.

Marketing as a business mean a system of two aspects of observation:

- Micro systems - micro marketing

\footnotetext{
${ }^{6}$ Vasilljev S, Marketing, Singidunum, Belgrade, 2004.
} 


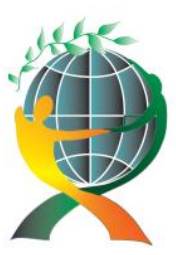

\author{
(online) $=$ ISSN $2285-3642$ \\ ISSN-L = $2285-3642$ \\ Journal of Economic Development, Environment and People \\ Volume 1, Issue 3, 2012 \\ URL: http://jedep.spiruharet.ro \\ e-mail: office jedep@spiruharet.ro
}

- Macro systems - macro marketing

Micromarketing is a micro system is, a subsystem of the organization as a system, and Macro marketing is an activity at the level of society, and the economy of a country.

Marketing as a scientific discipline is interdisciplinary, descriptive discipline that treats the phenomena related to the market. It has its own concepts and methods. In line with this, certain authors argue that marketing is a relatively new field of academic study and lacks theoretical basis that lacks diversity in provided areas such as economics, sociology and psychology. However, marketing theorists have tried to develop an independent marketing theory, as well as applying ancient theories in solving marketing problems. ${ }^{7}$

\title{
3.2. Relationship marketing and socially responsible marketing
}

The growth impact of relational marketing has been rapid. Relational marketing has found a ready acceptance throughout the world, because it has become apparent that a strategic competitive advantage can be provided only on the basis of product characteristics and that the profits of corporations is linked with customer satisfaction. In industrial marketing, marketing services, marketing and product management, distribution channels have passed their path of development from marketing of anonymous masses of consumers, through marketing relationships with more or less familiarity to consumers and other stakeholders, in other words consumers who can be identified. ${ }^{8}$

Stages in the development of business concepts are: product orientation, the orientation of the product, sales and commercial orientation and marketing orientation, which is now divided into customerorientation, orientation to the community and relational marketing.

There are several definitions of relationship (relational) marketing, according to which relationship marketing is "attracting, retaining and improving relationships with customers" (Berry 1983); marketing Relationship focuses on the development of long-term relationships with customers and other involved parties (Grönroos 1990), the purpose of Relationship Marketing is to establish, develop and enhance ... relationships with customers and other partners at a profit, in order to fulfil the objectives of the partners involved. This is achieved by mutual exchange and fulfilment of promises (Grönroos1996). Relationship marketing is also called marketing of relations, in particular literature, we find the term "retention

\footnotetext{
${ }^{7}$ Marie E. Murgolo-Poore, Leyland F. Pitt and Pierre R. Berthon, Three Theoretical Perspectives on One of Marketing's Most Fundamental Exchanges: Propositions on Personal Relationships, Marketing Theory 2003; 3; 235

${ }^{8}$ Egan J., Back to the Future: Divergence in Relationship Marketing Research, Marketing Theory, 2003.
} 


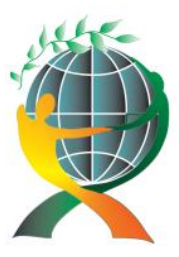

\author{
(online) $=$ ISSN $2285-3642$ \\ ISSN-L = $2285-3642$ \\ Journal of Economic Development, Environment and People \\ Volume 1, Issue 3, 2012 \\ URL: http://jedep.spiruharet.ro \\ e-mail: office jedep@spiruharet.ro
}

marketing". Relationship marketing redefines marketing as an investment for the future. ${ }^{9}$ In relational marketing, marketing efforts have been directed to carefully selected customers, whether it comes to an individual or groups, which adapt the product or service, but their interaction with all other participants is used to create and deliver a new, increased value. ${ }^{10}$

Market Model Six (The Six Markets model) refers to the relational marketing at the organizational level. It is understood that the role of the six markets, each of which represents a dimension of relational marketing, creates relationships with certain parties - organizations or individuals that can potentially contribute to, directly or indirectly on the effectiveness of the organization's positioning in the market. These domains were originally represented by the middle of the company which is regarded as the internal market, highlighting the role of internal marketing as an integrator and facilitator, which supports the management of relationships with other parties under other markets. ${ }^{11}$ Today, the consumer market is placed in the centre. Putting consumers at the centre of Six Markets model focuses on the purpose of relational marketing, creating value for consumers, satisfaction and loyalty, with the goal to increase profitability in the long run.

In relational (relationship) marketing, marketing efforts have been directed to carefully selected customers, whether it comes to an individual or groups, which adapt the product or service, but their interaction with all other participants is used to create and deliver a new, increased value.

Today, in the modern theory and practice there is an increasing discussion about the modern approach to marketing based on an interactional network, where marketing activities spread throughout the organization or outside of marketing. Marketing objectives, given its importance, become much more important objectives for the enterprises and organizations as a whole. This contributes to the development of total awareness of all employees in the company as well as importance of focusing on consumers and competition. $^{12}$

Thus, relational marketing is the highest level of development of marketing orientation, in other words the main task of relational marketing, is the guidance to build the optimal level of relations both with customers and with other groups that make up the micro-environment of the particular business system

\footnotetext{
${ }^{9}$ Woodcock N., Stone M., Machtynger L., "Customer relationship Marketing: Get to know yor Customers and win their loyalty", Kogan Page, 2002.

${ }^{10}$ Radnović B, Ilić M, "Costumer relationship management CRM software solutions and market-oriented enterprises", Proceedings of E-commerce 2008, Palic, 2008.

${ }^{11}$ Payne Adriane, Martin Christoper, Moira Clark, Helen Peck, Relationship Marketing for competitive advantage winning and keeping customers", Butterwort-Heinemman, 1999.

${ }^{12}$ Riznić D., Marketing Strategy of soft drinks producers, author, Kragujevac, 2003.
} 


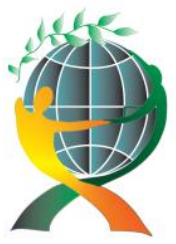

\author{
(online) $=$ ISSN $2285-3642$ \\ ISSN-L = $2285-3642$ \\ Journal of Economic Development, Environment and People \\ Volume 1, Issue 3, 2012 \\ URL: http://jedep.spiruharet.ro \\ e-mail: office jedep@spiruharet.ro
}

(suppliers, competitors, distributors and others). And which substantially determine the conditions and criteria of market economy in certain situations.

Relational marketing is an easily applicable concept for the revitalization of the marketing function and its re-assumption as the role of foundation management strategy throughout the organization.

Key requirements for the adoption of the concept of relational marketing are the following factors: ${ }^{13}$

- Reducing cycle time impact of marketing activities

- Modification of the access to the segmentation of a market

- Creating a preference towards products and services (individual preferences)

- Reducing the time frame for marketing research

- A different concept of marketing communications

- After Sales Communications Services

- The Customers desire to participate in decisions on prices..

The fact is that by increasing the aspects of nonmaterial relations with clients, companies that apply the relational marketing strengthen their competitive position, because intangible aspects, as opposed to tangible material such as leads, are not so easy to copy and imitate. ${ }^{14}$

In recent years, the approach in management that is based on relational marketing, relations with consumers is perceived as an asset of the company, which has brought many benefits, given the value of dedicated customers who are not sensitive to price changes, which reduced marketing costs or increased the total profits of the company. ${ }^{15}$

Exercise of success in business, with continuous customer satisfaction and all other stakeholders, is now closely associated with the acceptance and implementation of high standards in new forms of marketing that is called relationship marketing. In order to achieve the set business goals and success in the marketplace, companies need to evaluate actual practice of ethically and socially responsible marketing. Ethics has become a key element of the interaction between the company and its stakeholders. The new philosophy of the business-marketing relationship brings and points out at the importance of establishing, accepting that the maintenance and improvement of the deep relations between stakeholders, is the only path to success in the market. ${ }^{16}$

\footnotetext{
${ }^{13}$ Filipović V., Kostić - Stanković M., Marketing Management, FON, Belgrade, 2007..

${ }^{14}$ Sajeev Varki, Shirley Wong, “Consumer Involvement in Relationship Marketing of Services”, Journal of Service Research 2003.

${ }^{15}$ Woo Gon Kim, Jin Soo Han and Euehun Lee, Effects of Relationship Marketing on Repeat Purchase and Word of Mouth, Journal of Hospitality \& Tourism Research 2001; 25; 272

${ }^{16}$ Kovač-Žnideršić, R., and D. Marić. "Ethical dimensions of relationship marketing." Annals of the Faculty of Economics (2009): 147-156.
} 


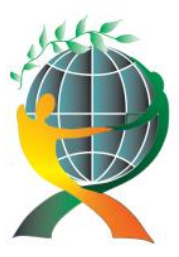

\author{
(online) $=$ ISSN $2285-3642$ \\ ISSN-L = $2285-3642$ \\ Journal of Economic Development, Environment and People \\ Volume 1, Issue 3, 2012 \\ URL: http://jedep.spiruharet.ro \\ e-mail: office jedep@spiruharet.ro
}

As one of the important principles of socially responsible marketing, we can quote: business ethics, human rights and labor rights of individuals and groups in the market, respect for environmental principles in the development of new products, fight against corruption in the market economy and respect for ethical principles in the design of communication with market groups.

Some of the key benefits of adopting the concept of socially responsible marketing are the following:

- Building a successful brand - connecting brands with socially responsible behavior, positive impact on sales and customer loyalty and devotion;

- Increasing the level of employee satisfaction in the service of marketing - engaging employees in socially useful projects, in accordance with the ethical rules, is one way to attract and retain quality staff;

- An increase in initiative and innovation - developing new ideas, perspectives and experiences, pointing out the need for new products, the ability to adapt technological and social changes and the like.

Due to a high importance of an environmental component in the management of marketing, originated a concept of ecological marketing, and eco-marketing. Ecological marketing assumes a series of changes:

- Customization of the products environmental standards,

- Changes in the process of production, delivery and consumption,

- Changes in packaging,

- Modifying the strategy of promotion and communication and so on.

One of the new concepts of marketing in the corporate social responsibility is called Cause Marketing (Cause related marketing), in other words the marketing of the occasion. The causal concept of marketing is a type of marketing that connects a company's contributions to the public good, with customers who directly or indirectly participate in transactions that bring the company revenues. D. Jobber is defined as a causal marketing commercial activity in which businesses and charities enter into partnerships with one another, for the sake of marketing a brand image, product or service, or for the sake of mutual benefit.

\title{
4. Conclusion
}

Corporate social responsibility is a frequently used concept in a modern business practice, given that the company is greatly responsible for the events and activities of a wider social significance. In an effort to 


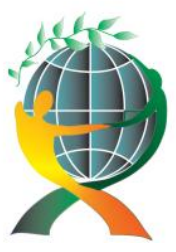

\author{
(online) = ISSN $2285-3642$ \\ ISSN-L = 2285 - 3642 \\ Journal of Economic Development, Environment and People \\ Volume 1, Issue 3, 2012 \\ URL: http://jedep.spiruharet.ro \\ e-mail: office jedep@spiruharet.ro
}

contribute to the solving of problems in the community in which they carry out their business, companies implement various corporate social initiatives.

Within the socially - responsible marketing the wider interests and ethical context of modern business is valued, with respect to legal and social regulation of marketing programs and activities. Modern companies in addition to meeting the needs, requirements and expectations of consumers should act towards appreciation and respect for the ethical norms and rules, and compliance with laws and regulations in order to achieve long-term results in business.

\title{
5. References
}

[1] Egan J., Back to the Future: Divergence in Relationship Marketing Research, Marketing Theory, 2003.

[2] Filipović V, Kostić M, "Marketing - Theory and Practice", FON, Belgrade, 2005.

[3] Filipović V., Kostić - Stanković M., Marketing Management, FON, Belgrade, 2007.

[4] Kotler P, Lee N, Corporate Social responsibility- Doint The most Good For Your Company“, John Wiley\&Sons, INC, New Jersey 2005

[5] Kovač-Žnideršić, R., and D. Marić. "Ethical dimensions of relationship marketing." Annals of the Faculty of Economics (2009): 147-156.

[6] Marie E. Murgolo-Poore, Leyland F. Pitt and Pierre R. Berthon, Three Theoretical Perspectives on One of Marketing's Most Fundamental Exchanges: Propositions on Personal Relationships, Marketing Theory 2003; 3; 235

[7] Milisavljević M., Marketing, Modern Administration, Belgrade, 2003.

[8] Payne Adriane, Martin Christoper, Moira Clark, Helen Peck, Relationship Marketing for competitive advantage winning and keeping customers", Butterwort-Heinemman, 1999.

[9] Radnović B, llić M, "Costumer relationship management CRM software solutions and market-oriented enterprises", Proceedings of E-commerce 2008, Palic, 2008.

[10] Radnović B., Ilić M, Živković Z, Corporate Social Responsibility and the nonprofit sector - a unethical marketing strategy or genuine concern, 3rd International Conference of Economic Sciences, Kaposvar 2011.

[11] Riznić D., Marketing Strategy of soft drinks producers, author, Kragujevac, 2003.

[12] Sajeev Varki, Shirley Wong, "Consumer Involvement in Relationship Marketing of Services", Journal of Service Research 2003.

[13] Todorović, J., M. Milisavljević, "Marketing strategy", Faculty of Economics, Belgrade, 1991.

[14] Vasilljev S, Marketing, Singidunum, Belgrade, 2004.

[15] Woo Gon Kim, Jin Soo Han and Euehun Lee, Effects of Relationship Marketing on Repeat Purchase and Word of Mouth, Journal of Hospitality \& Tourism Research 2001; 25; 272 


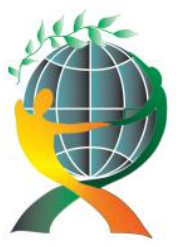

$$
\begin{gathered}
\qquad \begin{array}{c}
\text { (online) }=\text { ISSN } 2285-3642 \\
\text { ISSN-L }=2285-3642
\end{array} \\
\text { Journal of Economic Development, Environment and People } \\
\text { Volume 1, Issue 3, } 2012
\end{gathered}
$$

URL: http://jedep.spiruharet.ro

e-mail: office jedep@spiruharet.ro

[16] Woodcock N., Stone M., Machtynger L., "Customer relationship Marketing: Get to know yor Customers and win their loyalty", Kogan Page, 2002. 